TBGI Project Working Paper No. 29

\title{
Transnational Delegation, Accountability and the Administrative Governance of Biofuel Standards
}

\author{
Phillip Paiement ${ }^{1}$
}

\begin{abstract}
The European Union's 2009 Renewable Energy Directive delegated to privately run 'voluntary schemes' the task of monitoring biomass production sites and ensuring their compliance with the Directive's sustainability requirements. This chapter assesses the consequences of the Commission's delegation for the administrative governance architectures of non-state sustainable biofuel standards operating outside the EU, focusing in particular on the effects this governance interaction has on the involvement of vulnerable stakeholders in the governance of sustainable biofuels. Utilizing the Transnational Business Governance Interactions framework complemented by the theory of governance assemblages, this research provides a meso-level analysis of the character and effects of the EU's interaction with non-state governance schemes. Drawing on the Commission's assessment reports of the voluntary schemes with which it works, the chapter concludes that the Commission has avoided its role in reviewing the transparency of these non-state bodies, thereby stimulating the growth of a field of sustainability governance with decreasing levels of accountability and accessibility for vulnerable stakeholders.
\end{abstract}

\section{Keywords}

Sustainability standards, biofuel, Renewable Energy Directive, transnational private regulation, accountability, assemblages

\section{Introduction}

In 2009, the European Parliament and Council revised the Renewable Energy Directive (RED), establishing a target goal for Member States to utilize renewable energy sources for a minimum of $10 \%$ of their transport fuels by $2020 .{ }^{1} \mathrm{~A}$ series of criteria establishing the definition of 'sustainable' biofuels was included in the Directive, which aimed to conserve lands with high biodiversity value, limit greenhouse gas emissions, and avoid carbon stock losses related to biofuel production. ${ }^{2}$ However, as much of the European Union's (EU) biofuels are imported, monitoring the sustainability of biofuel production beyond its borders presents an extraterritorial governance challenge for the EU, requiring transparency and oversight of the global supply chains. The risk lies in unknowingly transitioning to biofuels that are not as sustainable as they appear upon first sight, and potentially even more harmful than current energy sources.

\footnotetext{
${ }^{1}$ Assistant Professor, Tilburg Law School, Tilburg University. p.m.paiement@uvt.nl. A revised version of this paper is forthcoming in Stepan Wood et al., eds. Transnational Business Governance Interactions: Empowering Marginalized Actors and Enhancing Regulatory Quality. Cheltenham, UK: Edward Elgar.
} 
To implement this Directive, the Commission has recognized certain 'voluntary schemes' whose standards ensure compliance with the sustainability criteria. ${ }^{3}$ Through reference to these schemes, which are non-state and voluntary standards, the EU has acknowledged the role that private supply chain governance can have in its own environmental and energy policies. The assemblage of EU institutions and voluntary schemes constitutes a type of transnational business governance interaction (TBGI) between state and non-state bodies. Delegating monitoring roles to the voluntary schemes has provided the $\mathrm{EU}$ with a transnational extension to implement its environmental policies concerning global biofuel production. Yet, it diverges from the wellestablished 'New Approach' of integrating production standards (Pelkmans 1987), opening itself to critique about participation, transparency and accountability in this new transnational assemblage of environmental governance.

This chapter assesses how the EU's reliance on voluntary schemes in the RED affects the administrative governance of biofuel production. In particular, it assesses two areas of impact: first, the challenges that this delegation presents to the EU's oversight mechanisms; and second, the organizational effects of the delegation on the field of non-state sustainable biofuel standards. In other words, the chapter is concerned with the effects of this delegation assemblage on the administrative practices of both the voluntary schemes and the EU as they relate to participation, transparency and accountability, with an ultimate concern for the consequences faced by structurally disempowered economic actors in the assemblage.

The chapter begins with the background context of the 2009 RED revision (section 2), followed by an elaboration of the assemblage theoretical framework (section 3 ). Next, it describes the two-step delegation comprising the RED assemblage, including the associated accountability concerns that have been introduced (section 4). It then assesses the resulting changes to the field of sustainable biomass standards and their accountability mechanisms (section 5), and explores the related consequences for marginalized stakeholders in biomass production (section 6).

\section{The EU and biofuel sustainability}

\subsection{The sustainability controversy surrounding biofuels}

The EU's 2003 Biofuels Directive established initial targets for the proportion of biofuels usage in Member States. ${ }^{4}$ Revisions in 2009 increased the goal for renewable energy usage to $20 \%$ by $2020 .{ }^{5}$ Preceding these revisions, however, the European Councils of March 2007 and March 2008 emphasized the need to consider the sustainability (in addition to the renewability) of biofuels, including impacts that biofuel production may have on agriculture and broader "environmental and social consequences of the production and consumption of biofuels." 6 This expanded the scope of the EU's biofuel policy to include the sustainability of biofuel production.

The Council's attention to sustainability occurred during a period of worldwide discussion about the desirability of biofuels as a source of renewable energy. Both the United States (US) and the EU had emphasized the growing importance of biofuels in their economies, for both energy independence and environmental concerns. Yet, there was a growing concern that biofuels were not inherently more sustainable than conventional energy sources due to social and environmental side effects associated with biofuel production.

First, with biofuel production concentrated in tropical regions, there were extensive concerns about tropical deforestation that could result from growing US and EU demands for biofuels. Secondly, biofuels came under criticism due to their social impacts on the price and availability of food crops for human consumption. In 2008, large fluctuations in world commodity prices, causing localized food crises, were attributed to the growing demand for biofuels (Mitchell 
2008). This 'food versus fuel' controversy caught considerable attention among political elites as the European Parliament was discussing future revisions of the Directive (Mol 2007; Partzsch 2009; Bailis \& Baka 2011). Jean Ziegler, the UN Special Rapporteur on the right to food, argued in a 2007 press conference that "[i]t is a crime against humanity to convert agricultural [sic] productive soil into soil which produces food stuff that will be turned into biofuel," and insisted on a 5-year moratorium on biofuels (UN News Centre 2007). Given the controversy, it became necessary for the EU to ensure that biofuels included in the EU's energy policies were not implicated in controversial conversions of food-producing land or other environmentally harmful practices.

\subsection{Sustainability in the 2009 Renewable Energy Directive}

The RED sustainability criteria constituted an essential piece of the 2009 revision of the Directive. Biofuels must meet the following criteria to be included in the renewable energy targets: their associated greenhouse gas emissions savings must be at least $35 \%$, increasing to $50 \%$ by 2017 and $60 \%$ by 2018; they may not be made from materials produced from peatland land with high biodiversity value or land with high carbon stock. ${ }^{7}$ Additionally, the Commission must report to the Parliament and Council every two years regarding the social sustainability of the global biofuel markets and production, and foodstuff affordability in developing countries. ${ }^{8}$

The Directive offers two options for monitoring compliance with these criteria. First, it obligates the Member States to require independent auditing of economic operators producing and trading biofuels. ${ }^{9}$ However, given that the criteria apply to biofuels produced both within and outside the EU, it was also necessary to establish monitoring systems for biofuels produced outside the EU's borders, which therefore would fall beyond the monitoring capabilities of the Member States. Thus, the Directive offers the Commission the opportunity to recognize 'voluntary schemes' that provide standards to demonstrate compliance with the criteria, effectively delegating monitoring powers to these non-state bodies. ${ }^{10}$ It further requires that any such schemes must meet "adequate standards of reliability, transparency and independent auditing." 11

In 2011, the Commission began recognizing the first voluntary schemes. It recognized an initial group of seven schemes (Commission 2011), which has since expanded to nineteen. While this delegation of monitoring to voluntary schemes provides a key tool for transnational implementation of the RED, it has also introduced a number of questions about how this new hybrid governance assemblage operates. In particular, there are significant concerns about the accountability and transparency of the monitoring that these voluntary schemes provide to the Commission, and questions as to where complaints about their compliance decisions should be heard.

\section{The assemblage in transnational business governance interactions}

The European Commission engaged in a new type of delegation when it began to recognize voluntary schemes as part of the implementation of the RED. The Commission had relied on voluntary schemes as one of numerous enforcement tools in its 2003 Forest Law Enforcement, Governance and Trade Action Plan, but the RED elevated the use of voluntary sustainability schemes to a new level (Overdevest \& Zeitlin 2014). The TBGI literature has accomplished an extensive mapping of theories of interactions in transnational governance, serving as a helpful beginning point (Eberlein et al. 2014; Wood et al. 2015). Transcending limitations to any one specific type of governance actor, the TBGI framework provides a 
comprehensive analytic perspective for studying governance assemblages involving public-public, private-public, private-private and other types of hybrid relationships (Zumbansen 2011). Through six governance dimensions (goal/agenda setting, rule formation, implementation, monitoring and information gathering, compliance promotion and enforcement, and evaluation and review) the TBGI framework helps in framing this study's analysis in theorizing of the character and effects of interactions (Eberlein et al. 2014, p. 6).

In the language of the TBGI literature, this study is an example of a 'meso-level' analysis focused on "interactions among TBGI schemes, and between them and state-based regulators" (Eberlein et al. 2014, p. 8). Furthermore, we are presently concerned with 'conditional referencing' mechanisms, insofar as the Commission makes compliance with the RED sustainability criteria conditional on certification of a product's supply chain and production methods in accordance with a recognized voluntary standard scheme. This study interrogates the character of these interactions to assess whether they exhibit competition, coordination, cooptation, or chaos. Finally, this study is concerned with the effects of the interaction, including the following possibilities mapped out in the TBGI literature: increases in regulatory capacity and performance, 'races to the top' and 'races to the bottom', as well as 'homogenization' of voluntary standards (Eberlein et al. 2014, p. 11-13).

Abbott and Snidal's theory of regulatory orchestration in transnational new governance plays a formative role in TBGI scholarship. This theory arises from the observation that transnational new governance - characterized by high decentralization of regulatory activities, fragmentation of regulatory expertise and capacities, and the extensive use of voluntary codes could be improved through greater orchestration by states and intergovernmental organizations (Abbott \& Snidal 2009; Abbott et al 2015). This current study could certainly be approached from the perspective of the EU's orchestrating role. In fact, Schleifer provides a compelling account of the RED as a partial failure in regulatory orchestration insofar as "EU regulators have failed to establish a level playing field among biofuel certification schemes," facilitating forum shopping and negative forms of competition among standards bodies (Schleifer 2013, p. 542).

While many of the findings in Schleifer's study will be echoed below, there are aspects of the theory of orchestration that prove problematic for studying the delegation interactions comprised in the RED. First and foremost, the theory of regulatory orchestration presumes that the state acts as a single homogenous entity. This traces back to the theory's origins in the 'new governance' context: "In New Governance, the state remains a significant player, but as an orchestrator rather than a top-down commander" (Abbott \& Snidal 2009, p. 521). This approach would force an analysis of the EU as a single actor, rather than looking into more nuanced dynamics between competing branches of the EU. In addition, the regulatory orchestration theory views the state's engagement in transnational regulatory spaces as a new phenomenon breaking with historical practices of 'old governance'. This assumption overlooks the lengthy history of states engaging with transnational business governance (e.g. Cutler 2003). Finally, the theory approaches orchestration as a normatively desirable practice of the state, aimed at achieving effectiveness, transparency and empowerment of marginalized groups in transnational governance (Abbott \& Snidal 2009, pp. 564-577). This is what allows Schleifer to speak in terms of 'success' and 'failure'. However, such an approach presumes normative agreement as to what ought to be the ends of orchestration, a contentious issue in itself. Instead, it would be more beneficial to orient the current analysis towards the question of what kind of regulatory work the EU's orchestration is producing, rather than immediately assessing its desirability.

Another way to look at this arrangement is as a regulatory 'assemblage' of public actors (the Commission, the Parliament), NGOs (the voluntary schemes), and private companies (supply chain corporations) (Ponte \& Daugbjerg 2015; Mol 2010). The concept of assemblages arises from 
the social-ontological work of Deleuze and Guattari (Deleuze \& Guattari 1987, p. 88; Delanda 2006a). Assemblages are scalar relationships between smaller parts assembled into a greater large-scale entity (Delanda 2006b). The interacting constituent parts of an assemblage are often themselves assemblages of other lower-level parts. Furthermore, the large-scale entity is immediately engaged in constituting its parts by empowering them with resources and constraining them with limitations (Delanda 2006b, pp. 251-252). Finally, assemblages are characterized by the presence of contradictory territorialization and deterritorialization processes which respectively stabilize and de-stabilize the assemblage's identity (Delanda 2006b, p. 253). The concept of a regulatory assemblage is comparable to Perez's notion of 'ensemble regulation' in that they both emphasize networks of constituent elements of various types of actors (Perez 2011). However, the focus of ensemble regulation on positive externalities produced by networks that are oriented around a common set of principles contrasts sharply with the internal contradictions and tensions that are presupposed in the regulatory assemblage framework.

Sassen's historical analysis of territory, authority and rights has influentially translated the concept of 'assemblages' for transnational governance research (Sassen 2006; Sassen 2008). Sassen's work postulates that transnational or global assemblages of public authorities and private market actors from seemingly contradictory and competing levels (national versus transnational) and sources of authority (state versus market) asymmetrically empower particular elements of each competing authority and level. Sassen describes how national executive bodies have frequently been empowered, at the expense of national legislative and judicial bodies, in their engagement with transnational market authorities (ibid; see also Sullivan 2014; Valverde 2015).

Viewing transnational governance arrangements as 'assemblages' simultaneously emphasizes the inter-related spatial and temporal dimensions of governance. More specifically, the assemblage framework focuses on the dynamics of contradictory processes of globalization that are territorializing and de-territorializing in the form of globalized localisms and localized globalisms (de Sousa Santos 2002). Lastly, it emphasizes interdependent and polycentric governance architectures rather than privileging the formal authority of nation states and international organizations (Ponte \& Daugbjerg 2015).

In comparison to regulatory orchestration, an assemblage framework thus offers a more appropriate lens for assessing the EU as a multi-interested, complex actor in the transnational delegation constructed in the RED. It opens up the possibility of seeing particular entities in the EU and biofuel production being (dis-)empowered in different ways as a result of their interactions. This is further premised on an assumption that there are multiple, competing, and conflictual visions of biofuel sustainability that different actors are pursuing in their engagement with the governance assemblage. Assemblage theory also embeds the analysis within the spatiotemporal dimensions of biofuel sustainability. As Ponte and Daugbjerg note, the problem of biofuel sustainability governance is premised on the fact that the sustainability of a biofuel cannot be measured by its end product. The RED thus serves to build connections among the fragmented spaces and moments of biofuel supply chains which implicate biofuel sustainability (Ponte \& Daugbjerg, p. 104). Ultimately, assemblages offer a useful concept for capturing the extensive layers of actors, norms and processes with contradictory interests and purposes that are brought into relationship with each other because of the RED (Zumbansen 2012). It does this without presupposing what would constitute a 'success' or 'failure', but rather in terms of (dislempowerment. With this framework of TBGI assemblages in mind, the next section assesses the relationship between the Commission and the voluntary schemes and places it in comparison to the Commission's more common relationships with standard setting and monitoring bodies. 


\section{The Commission's delegation to voluntary schemes}

The European Commission has a long history of delegating tasks to private organizations responsible for technical standards, although it is important to approach this history within the context of the delegation of legislative power from the Council to the Commission. In this sense, there is a two-step process of delegation in which the Commission's relationship with standard setting bodies must be assessed.

The Council frequently delegates legislative powers to the Commission in order for regulatory action in the EU to remain effective and efficient (Craig \& de Búrca 2008, p. 118; Bergström 2005). The European Court of Justice (ECJ) affirmed the validity of this type of delegation in the Koster decision. ${ }^{12}$ Article 290 of the Treaty on the Functioning of the European Union provides the Council and Parliament the possibility of delegating power to the Commission to adopt 'non-legislative acts of general application,' and Article 291 provides for delegating 'implementing powers' to the Commission. While the distinction between these two types of powers has its grey margins, the inclusion of these provisions in the treaty has been widely considered a positive step towards further institutionalizing historically common delegation practices (Ponzano 2008; Craig 2008).

The Commission received a series of implementing powers in the RED, which states that, "[t]he Commission shall maintain a dialogue and exchange information with third countries and biofuel producers, consumer organisations and civil society concerning the general implementation of the measures in this Directive relating to biofuels and bioliquids." ${ }^{13}$ This delegation of powers occurs within the tension between the democratic and national accountability provided by the Parliament and Council and effective implementation best provided by the Commission. Yet, as the Council and Parliament delegate power they simultaneously include constraint mechanisms such as the information exchange requirements noted above and a 'Committee on the Sustainability of Biofuels and Bioliquids' for Member States to provide input and direction to the Commission's implementing measures. ${ }^{14}$ In this respect, this delegation in the RED follows a well-established pattern of practices in the EU's institutions.

A second step of delegation frequently occurs within the Commission's own implementing measures, which is where delegation in the EU becomes more problematic. It is difficult to maintain accountability when the Commission delegates authorities to other actors (eg. EU agencies). For example, the comitology committees and other EU agencies are not formally subject to the jurisdiction of the European Court of Justice, and it is difficult for courts to review their actions (Curtin 2007, p. 535). Despite these concerns, in its 1958 Meroni decision the ECJ upheld the Commission's delegation of powers to third parties, even private actors. ${ }^{15}$ This protection is contingent on a series of provisos established in that decision, including that the delegated powers must be powers that the Commission enjoys; they must be clearly defined and strictly executive; they must be subject to the same conditions as if they had been exercised by the Commission; and the Commission must continue to supervise their use. ${ }^{16}$ More than half a century later, these criteria remain influential in the ECJ's reasoning (Dehousse 2002).

\subsection{The Commission's 'New Approach' to standards}

Since 1985, the New Approach has structured the Commission's delegation to non-state standards bodies. It requires that Directives on issues such as product safety and building safety provide only 'essential requirements' (Pelkmans 1987), ${ }^{17}$ leaving details to be set out in technical standards issued by European standards bodies. Conformity with the standards, while formally voluntary, is considered equivalent to compliance with the essential requirements (Schepel 2005, pp. 227-228). Through this procedure, the EU is able to generate technical specifications 
efficiently, yet it does not fully delegate powers to standards bodies as compliance remains formally possible without the standards. Importantly, the Commission itself does not substantively review the standards in this procedure (Schepel 2005, pp 235-239). As Schepel notes, there are clear inconsistencies between the 'New Approach' and the Meroni decision in that "[t]he powers of the European standards bodies go far beyond 'implementation'; there is no control or supervision of the Commission or possibilities of judicial review" (Schepel 2005, p. 227). Admittedly, the Council strengthened the accountability of the delegation procedure with legislation requiring greater transparency, qualified majority decision-making, and the involvement of different types of stakeholders (Schepel 2005, pp. 242-246). ${ }^{18}$ Yet, it has become more apparent that the 'New Approach' constitutes a more significant delegation of powers than once believed, requiring more attention to the decision-making procedures of delegated bodies. It is worth noting that the recent decisions in the Fra.bo and Elliott James cases have further complicated the status of the New Approach and opened the doors to a substantive review of private standards by the ECJ (Schepel 2013). ${ }^{19}$

\subsection{A 'different approach' in the RED}

The EU's approach to the voluntary schemes in the RED is rather different from its New Approach to technical standards. The New Approach to technical standards is generally limited to issues that affect product characteristics, while the RED voluntary schemes monitor production processes that go well beyond visible or traceable effects on the quality or nature of the product. ${ }^{20}$ For example, whether or not palm oil originates from palms grown in former tropical forests would not have an effect on the character or quality of the palm oil. Whereas the EU's New Approach technical standards originate from national and European standards bodies, the voluntary schemes involved in the RED arise from bodies whose work is generally delineated by industry sectors rather than by national borders, and whose operations are better characterized as transnational. The Commission maintains a comprehensive list of national standardization bodies that excludes the RED voluntary schemes (European Commission 2017). The International Organization for Standardization (ISO) also distinguishes between its member bodies (national standards bodies) and other "private standards" (ISO 2010). In other words, the voluntary schemes embraced by the RED constitute a new genus of standards for the EU. There are other notable fields of standardization in which the EU has diverged from its New Approach, such as food quality and safety standards, which also include transnationally oriented standards composed by industry actors, multi-stakeholder platforms, and other organizations, in addition to recognized national standard-setting bodies (Verbruggen \& Havinga 2017).

Without the structural constraints of the New Approach, the delegation of monitoring and enforcement roles to voluntary schemes constitutes an ad hoc form of conditional referencing governed by an equally ad hoc set of measures in the RED. In July 2010, the Commission announced the procedure and requirements by which voluntary schemes would be recognized for purposes of compliance with sustainability criteria (European Commission 2010). This action was pursuant to the Commission's powers ascribed by Article 18(4) of the Directive. ${ }^{21}$ However, the Directive also requires that "[t]he Commission shall adopt decisions under paragraph 4 only if the agreement or scheme in question meets adequate standards of reliability, transparency and independent auditing." 22 This trio of reliability, transparency, and independent auditing provide the ad hoc accountability structure of delegation for this interaction between the Commission and voluntary schemes.

The Commission's recognition guidelines provide thorough requirements for assessing the reliability and independent auditing of voluntary schemes. They require that "[schemes] have 
an auditable system for the evidence related to the claims they make or rely on, keep any evidence for a minimum of five years, and accept responsibility for preparing any information related to the auditing of such evidence" (Commission 2010, section 2.2.1). They include requirements ensuring sophisticated audits, including tailoring auditing procedures with respect to the particular risks posed by the economic operator, establishing verification plans appropriate to the scope and complexity of the audited operations, and obtaining missing documentation or explanations before finishing audits. The Commission also requires that audits be independent insofar as they must be performed by neither the economic operator nor the voluntary scheme (Commission 2010, section 2.2.1).

Despite the elaboration of requirements for reliability and independent auditing, the Commission's communication does not contain any mention of the transparency of voluntary schemes. Its Assessment Protocol template is more illustrative of the transparency requirements considered in the assessment of schemes. Under section 6.13 "Transparency", the Commission requires that voluntary schemes make available the following information: list of certified economic operators and those who are no longer certified, "the latest version of scheme documents including the guidelines for audits", certification bodies accepted by the voluntary scheme, and contact details of the organization responsible for the voluntary scheme (Commission 2015b). Thus, while the Commission rarely addresses this third dimension of its accountability structure, there are at least minimal requirements formally included in the assessment procedure.

Since 2011, the Commission has recognized 19 voluntary schemes as sufficient for monitoring compliance with the Directive's sustainability criteria. As of December 2017, 16 schemes are recognized as a number of the Commission's decisions have expired without renewal. In reviewing their assessments, it is clear that the Commission recognized all of the schemes before the current Assessment Protocol template was in use. Section 6.13 on transparency of the current template is not included in any of the assessments (Commission 2015b). In fact, not a single assessment conducted so far by the Commission includes any review whatsoever of the organizational transparency of the voluntary schemes that the Commission is recognizing.

The Commission introduced the heightened transparency evaluation measures in reaction to the 2015 Indirect Land-Use Change Directive, which amended the 2009 RED (Commission 2015a; Commission 2015c). ${ }^{23}$ This recent Directive further entrenches the trio of principles concerning reliability, independent auditing, and transparency of voluntary schemes. The Commission is now required to report to the Parliament and Council on the transparency of voluntary schemes, including "the accessibility of the scheme, the availability of the translations in the applicable languages of the countries and regions from which raw materials originate, the accessibility of a list of certified operators and relevant certificates, and the accessibility of auditor reports." 24 Furthermore, the amendments have introduced additional accountability requirements concerning the involvement of stakeholders - including vulnerable groups such as indigenous and local communities - in the decision-making processes during the drafting and revision of the schemes. These changes have resulted in a more thorough accountability structure for the delegation of monitoring roles to voluntary schemes, but the new requirements have not yet been used. Eventually, however, all of the currently recognized schemes will require reevaluation by the Commission with the more stringent procedure.

In summary, while the trio of transparency, independent auditing, and reliability have served as a main accountability structure for the conditional referencing of voluntary schemes under the RED, for the first four years of operation the Commission completely ignored transparency concerns. The recognition process has emphasized function over form; confirmation 
that the scheme's requirements and measurement processes adequately meet the policy goals has been the overriding priority, while the Commission eschewed any serious review of organizational transparency and public participation in standard setting. Having provided this descriptive account of the nature of the delegation interactions between the EU institutions and voluntary schemes, the next section will shift focus to the effects that the interaction has had on the field of voluntary schemes.

\section{Transformations in the field of transnational standards for biomass sustainability}

This section evaluates the impacts that the conditional referencing interaction has had on the field of transnational sustainability standards. In particular, the analysis will initially address the proliferation effects created by the possibility of conditional referencing, and subsequently, the variation in administrative formats among the voluntary schemes that have arisen with this proliferation.

Before beginning this analysis, it is important first to establish the parameters of the voluntary schemes examined below. As this chapter is concerned with the transnational dimensions of the RED achieved via interaction with voluntary schemes, the scope is limited to schemes operating outside the EU. The scope thus includes the following ten schemes:. International Sustainability and Carbon Certification (ISCC), Bonsucro EU, Round Table on Responsible Soy (RTRS) EU Red, Roundtable of Sustainable Biofuels (RSB) EU RED, Biomass Biofuels voluntary scheme (2BSvs), Abengoa RED Bioenergy Sustainability Assurance (RBSA), Greenergy, Rountable on Sustainable Palm Oil RED, Neste Oil's HVO Renewable Diesel Scheme, and NEN's NTA $8080 .{ }^{25}$ The other nine schemes recognized by the Commission either operate only within the EU or are limited to a greenhouse gas calculation tool rather than a fully-fledged sustainable biofuels standard.

\subsection{The proliferation of a standards market for sustainable biomass}

An initial effect of the RED was a proliferation of sustainable biomass standard-setting schemes (Reinecke et al. 2012). Of the ten schemes recognized by the Commission, only seven were operating sustainable biomass standards before the revised RED came into effect: ISCC, Bonsucro, RTRS, RSB, RSPO, NEN and Greenergy. The other three schemes, 2BSvs, RBSA, and Neste Oil's HVO scheme, were all initiated explicitly in response to the voluntary schemes provision in RED. In addition, NEN's NTA 8080 standard was first created in 2009, the same year that the RED was revised, technically pre-dating the legislation but likely written with it in consideration. Hence, the introduction of the RED's conditional referencing possibility acted as a driver for at least three transnational standard-setting organizations to enter the field of biomass sustainability standards.

In addition to the proliferation of standard-setting schemes, the conditional referencing possibility was also responsible for the proliferation of standards in the field of sustainable biomass. Of the seven schemes already operating standards for sustainable biomass, four schemes created add-ons to their pre-existing standards to meet the RED criteria. This approach, taken by RTRS, RSB, Bonsucro, and RPSO, introduced an additional layer of complexity to each organization's standards. Now, they each have a baseline standard applicable to all of their certified operators, plus an EU RED add-on for those who seek RED compliance. Hence, the conditional referencing possibility is also directly responsible for four new standards from pre- 
existing bodies. In this sense, the RED has contributed to a proliferation of standards for biomass sustainability.

Both homogenization and fragmentation dynamics arise from the proliferation of standards and standard-setting bodies. The fact that the majority of recognized schemes were either created explicitly with the RED in mind or constitute add-on options for already existing schemes suggests that there has been some homogenization towards more stringent components in standards, although this is limited to very specific issues within the standards. For instance, it is common for pre-existing schemes to add provisions regarding historic land-use change restrictions and a greenhouse gas emissions calculation tool to their standards in order to integrate the EU's sustainability criteria, as RSPO has done for its RED standard. These changes are aimed to prevent entry of biofuels produced on recently converted forestland or peatlands as their conversion to agro-industrial plantations results in excessive carbon emissions. Strikingly, only one recognized scheme (NEN's NTA 8080) has created an 'opt-out' version of their standard that allows for pre-existing standard users to opt for a less stringent standard if they are only interested in compliance with the NTA 8080 for the purpose of gaining recognition as a sustainable biofuel under RED. Thus, looking narrowly at the specific issues for which new criteria are being added into standards (land conversion, greenhouse gas emissions calculations), the EU RED requirements are contributing to a degree of upward homogenization for those issues. However, as Schleifer rightly points out, the prevailing general trends is that the new standards are overall less stringent than pre-existing ones and there is no trend towards homogenization in any comprehensive sense. (Cashore et al. 2007; Schleifer 2013). For example, the new 2BSvs and Neste Oil standards cover only the substantive areas required by the RED: conservation of land with high biodiversity, limitation of greenhouse gas emissions, and the avoidance of carbon stock losses in biofuel production. In contrast, the pre-existing RSPO and RSB standards include a much wider array of environmental issues, such as soil erosion and fertility, pesticide use and storage, and waste reduction strategies. They also include social standards pertaining to labor rights and the land rights of local communities. The extensive considerations in these pre-existing standards do not appear in the standards created after the introduction of the RED.

The Directive has also caused a degree of fragmentation regarding the organizational formats of the standard-setting bodies involved. Four of the seven organizations pre-dating the RED self-identify as 'multi-stakeholder initiatives' (RSB, RSPO, RTRS, and Bonsucro), while another has been frequently considered an industry-dominated body (ISCC), and the last was created by the Dutch national standard setting body (NEN's NTA 8080) (Ponte 2014, p. 268). The schemes that were developed in response to the RED have introduced considerably more diversity into this field. Some are individual corporations using their own in-house standards for their value chains (e.g. Neste Oil's HVO scheme, Abengoa's RBSA scheme), while others are created by trade associations and other groups of economic operators (e.g. REDCert, 2BSvs). This fragmentation raises concerns about the accountability, transparency and legitimacy of these new standard setting bodies, which will be addressed in the following sections.

\section{2 (Un)accountability in diverse administrative structures}

This second section of the analysis focuses on the organizational formats of the voluntary schemes recognized by the Commission. It is concerned with variations in the actors involved in decision-making procedures regarding their standards, the possibilities of public participation in their standard setting and governance, and institutional transparency concerns. In other words, it is concerned with their administrative governance structures. 
The six recognized schemes that were already active in sustainable biomass standard setting before the Commission began its recognition assessments have rather stringent and comprehensive administrative governance practices. At the time, RSB was a Full Member and Bonsucro an Associate Member of the ISEAL Alliance (ISEAL), a non-state 'meta-standard'-setting umbrella group for sustainability standard-setting bodies. ISEAL is an influential voice in defining credible and legitimate standard-setting for sustainability governance (Reinecke et al. 2012, p. 33; Loconto \& Fouilleux 2014). Shortly afterward, in 2012, RSPO also become an Associate Member the process for which must have begun prior to the Commission's initial recognition of schemes in 2011. These organizations' ISEAL membership signifies their use of stringent procedural standards for their governance, with Meidinger likening the stringency and thoroughness of ISEAL's codes to the US Administrative Procedure Act (Meidinger 2006, p. 69). ISEAL maintains Codes of Good Practice for Standard-setting, Assurance and Impacts, all three of which provide robust requirements for the governance and implementation of sustainability standards with the Standard-setting Code most relevant for the concerns of this chapter. The Standard-setting Code includes requirements such as that participation in governance bodies creating standards should be open to all stakeholders and be composed of a 'reasonable balance' of stakeholders, that standards creation and revision should include public notice and comment procedures, that standards should be publicly available online, and that the procedures of standards development and revision should be transparent (Paiement 2016; Wood 2016; ISEAL Alliance 2014). RSPO, Bonsucro and RSB must have been compliant with ISEAL's Standard-setting code when the RED was revised in 2009, as both full and associate membership requires compliance with it. Compliance is initially verified through an independent evaluation conducted by ISEAL's staff, and is subsequently monitored through peer evaluations by other ISEAL members. In light of Bonsucro, RSPO and RSB's ISEAL membership, their performance regarding the actors involved in decision making, public participation in standard creation and institutional transparency can be considered a high positive performance. For example, all three have a primary governance body ('assembly' or 'council') composed of representatives from various trade sectors, as well as environmental and social NGOs. Likewise, they each use public notice and comment periods in the revision of their standards. In summary, their administrative governance demonstrates high levels of transparency, public participation and multi-stakeholder decision-making and is held to these high levels by an independent organization, ISEAL.

While RTRS is not an ISEAL member, it is a 'subscriber' in ISEAL's organization and has a multi-stakeholder governance format comparable to RSB, RSPO and Bonsucro. It's primary governance body is the 'General Assembly' which is composed of voting members representing Producers, Industry, Trade \& Finance, and Civil Society sectors. Its most recent standard revision process was conducted using three public notice and comment periods, resulting in more than 250 comments (RTRS 2017). The technical body which ultimately composed the most recent standard included balanced participation from Producers, Trades and Civil Society representatives, as did the technical bodies responsible for earlier versions (ibid, RTRS 2013). As such, RTRS performs at similar levels as the ISEAL member standards, albeit without the extra guarantee of independent verification of its governance practices by ISEAL. As such, four of the pre-existing standards were developed in accordance with the most concrete and robust global administrative norms for standardization in sustainability governance.

The NEN organization responsible for NTA 8080 is a national standard setting body from the Netherlands. As the national member of the International Organization for Standardization (ISO), NEN is obligated to utilize standard-setting processes which comply with the ISO's requirements concerning the transparency and the participation of stakeholders in the standard setting-process (ISO/IEC 1995). For example, NTA 8080 was initially written by a technical 
committee of 25 individuals representing universities, environmental NGOs, trade associations, businesses (including Shell), and public authorities (i.e. Dutch Ministry of Economic Affairs) (NEN 2009). While this entails a broad representation of stakeholders, they are all notably based in the Netherlands despite that the standard is explicitly developed from global utilization. Furthermore, while NEN's standard setting process is fairly transparent, there is no evidence that a public notice and comment was utilized in the development of NTA 8080, bringing into question whether affected stakeholders outside of the Netherlands were able to provide input in the standardsetting process (NEN 2017). As such, the NTA 8080 standard could be said to perform at a moderate level in terms of the actors involved in decision-making and transparency, and a low level for public participation.

The remaining pre-existing standard, ISCC, had a less exemplary administrative governance structure at the time. It has been criticized for having close ties to biomass and biofuel traders (Ponte 2014). Only after having produced its standard did it proclaim itself a multistakeholder organization. They have now introduced a General Assembly of stakeholders to partake in the standard development process for future revisions, although the Assembly does not used balanced forms of representations for different classes of stakeholders like the ISEAL members (ISCC 2011). The ISCC Board does reflect a tripartite representation of producers, traders and civil society organizations (NGOs, researchers, and public sector organizations) (ibid). Despite participation from organizations like the World Wildlife Fund, the General Assembly members that constitute the ISCC Association are still overwhelmingly downstream industry actors. Of the roughly 100 members currently listed on their website, no more than ten are identifiable as belonging to civil society sector (ISCC 2017a). In terms of transparency and public participation, ISCC now utilizes public comment periods for their standards, the audit reports for producing entities certified by ISCC are not publicly available, although there is currently a working group to improve this issue of transparency (ISCC 2017b). In summary, despite having improved on a number of governance concerns, ISCC still performs at only a moderate level for public participation, transparency and the actors involved in decision-making.

The four new organizations following the introduction of the RED scheme demonstrate remarkably less extensive governance systems. Neste Oil developed its own standard for use within its supply chain, despite also using both ISCC and RSPO for different operations within its corporate family. There is no account provided as to how their standard was written and whether stakeholders within their supply chain participate. The 2BSvs Consortium is composed of collectives of economic operators in biomass industries and there is scarce public information about the process by which the standard was created and whether stakeholders participated (see 2BSvs 2016). Furthermore, much of the administrative work surrounding the standard has been contracted out to their 'Technical Advisor', the auditing firm Bureau Veritas. Abengoa Bioenergy's RBSA standard was developed primarily for use within its own value chains. Aside from brief yearly reports, there is no transparency as to the standard writing procedures or stakeholder participation possibilities. In its most recent Annual Report, for 2013-2014, the company states that "[a] team takes care of the continuous keeping and improvement of the management system as far as objectives, contents and management are concerned," without providing further information about the team (Abengoa Bioenergy 2014, p. 10). The fourth organization, Greenergy, is no longer listed as a recognized scheme since its recognition elapsed in June 2017. It also appears from its website that it no longer maintains a standard for sustainable biofuel production. In any event, Greenergy is a UK-based private limited liability company that supplies fuel throughout the EU. There is no indication that external parties were involved in the creation of the standard, and it appears to have only been used internally within Greenergy's own supply 
chain (Greenergy 2011). In short, all four of these new organizations perform at low levels for public participation, transparency and multi-stakeholder decision-making processes.

A possible hypothesis for explaining the effect that the RED had on biofuel standards is that the RED may have offered a platform for public exchange of biofuel sustainability standards and their associated governance processes. As a consequence, it could be hypothesized that newer standards bodies simply took organizational shortcuts and borrowed from existing standards bodies without the thorough development procedures exercised by earlier standards. This hypothesis can be considered on two separate levels. In terms of the substantive content of biofuel standards, the hypothesis might have some purchase, but it would need to be demonstrated by a substantive review of the standards' policies, which goes beyond the scope of this chapter. In terms of the development and administration of the standards, the primary concern here, this hypothesis does not hold water. As the analysis has shown above, if anything there is more diversity in terms of the dispute procedures, transparency standards, and accountability mechanisms. Whether the less accountable and less transparent formats of the new schemes were chosen for strategic purposes related to the biofuel controversy, or simply to save time and costs, or a combination of both, is difficult to say and a moot question insofar that the Commission has tolerated these practices that derogate from the requirements set forth in the RED.

In summary, the RED's effects on the field of sustainable biomass standards have been a decrease in accountability, transparency and participatory opportunities for stakeholders. The Commission's choice to forego assessments of transparency undoubtedly facilitated these developments. Breaking this regulatory assemblage down into constituent elements illustrates the asymmetrical dynamics of empowerment. The Commission's interests in increasing biofuel trade, and the position of industry-led standards, have been empowered by the assemblage. The accountability concerns of the Parliament and Council, as well as the position of multi-stakeholder standards, have lost out. Rather than speaking of 'success' or 'failure', the assessment of the RED as an assemblage demonstrates, in all its contradictions, how the goal of increasing transparency and accountability in global supply chains has simultaneously facilitated the development of unaccountable private governance. Next, we identify what is at stake for marginalized stakeholders in this increase of unaccountable administrative structures of private governance.

\section{The fate of stakeholders when the EU's sustainable trade policies go global}

The EU's recognition of voluntary schemes has raised a number of criticisms. Criticisms related to environmental and social effects of the RED are connected to the above analysis of the character of the interaction and its consequences for biomass sustainability standards and their administrative governance structures. In drawing these relationships, this last section discusses the significance of this particular manifestation of a transnational business governance interaction and critically reflects on the governance work that it accomplishes from the perspective of disempowered stakeholders.

Critics have pointed to the possible negative consequences of a more crowded field of standards. Some have argued that the proliferation of standards 'may become a major barrier to trade in the absence of harmonisation of standards or of mutual recognition of conformity assessment reports' (Zezza 2012, p. 47). Others have noted that there is considerable diversity among the multiple greenhouse gas calculation tools recognized by the Commission, and that producers can enhance their emissions performance on paper by as much as $20-35 \%$ simply by 
strategically using different calculation tools (Hennecke et al. 2013). Hence, the multiplicity of recognized standards, combined with a lack of harmonization mechanisms, raises concerns about the ability of this governance interaction to achieve the climate change mitigation goals of the RED by incentivizing trade in sustainably sourced biomass.

More disturbing, however, are accounts of how this interaction works to introduce the EU's climate change mitigation goals within the production sites of biomass across the Global South as priorities, while ignoring and overriding local and national natural resource and socioeconomic development interests of producer countries (German \& Schoneveld 2012, p. 776). Looking into the effects of the biofuel policy in Brazil and Mozambique, one study remarked that the EU's policies and the recognized schemes often approach natural resource and socioeconomic issues from very different perspectives than that of local communities, resulting in 'frictional encounters' between the global biofuel value chains and these communities (Franco et al. 2010). For example, "treating land as 'marginal' can justify its appropriation for agro-industrial biofuels, but may provoke protest from local poor people being dispossessed. Meanwhile, agroindustrial plantations may create 'employment' but then also degrade its conditions and readily undermine other livelihoods in the informal economy" (Franco et al. 2010, p. 691). As such, a key concern has become the balance between the pursuit of globally applicable governance frameworks for sustainable biomass while maintaining sensitivity to the local heterogeneity of environmental and socio-economic interests. Critically, this may also include differentiation among governance mechanisms to make it easier for low-risk smallholders and informal producers to enter sustainable biomass markets while high-risk agro-industrial producers are still held to stringent standards (Schut \& Florin 2015).

The ability of the EU's energy policies to override local and national interests in producing countries is all the more problematic given the accountability structures defining the EU's delegated interactions. As argued above, the Commission's recognition process is unclear and it has so far foregone any substantial review of the transparency of schemes (Romppanen 2013, p. 343). The accountability concerns raised here spread even further into the interaction assemblage. Romppanen has criticized the dual public and private roles that the verifiers of conformity to the schemes' standards play in this assemblage: "As delegated agents, verifiers are required to apply central demands of good administration and answer to the legal requirements set for the sustainability of biofuels. As business actors, verifiers are to be competitive and respond to the needs of the biofuels market" (Romppanen 2013, p. 349). The concern is that their conflicting interests could lead to a form of capture in which their public function becomes neglected and priority instead given to their commercial competitiveness, a familiar concern in private verification scenarios (Lytton \& McAllister 2014).

Furthermore, as demonstrated above, the majority of the schemes developed in response to the RED have opaque or underdeveloped administrative governance structures, with limited or no opportunities for public participation and without transparent decision-making procedures. This poses problems for local communities affected by biomass production. For example, in a palm oil producing region of Indonesia's Central Kalimantan province, researchers have concluded that "[ $t$ ] he most fundamental flaw in the existing governance system is that affected communities such as those around Lake Sembuluh, despite multiple performance standards and sources of authority, still do not have access to functioning recourse mechanisms and remedies" (Larsen et al. 2012). The lack of transparency and public participation mechanisms, in both the Commission's recognition of schemes and the schemes' own internal governance, has resulted in systemic unaccountability.

A two-decades-long land dispute in Malaysia tied to the global trade pressures of renewable biofuels illustrates the significance of unaccountability in the RED interactions. Since 
1996, the indigenous community of Long Teran Kanan has been in a dispute with the palm oil production company Rinwood-Pelita and later, its successor IOI-Pelita Plantations (Colchester et al. 2012; Lucas 2013). At the core of the dispute lies the local community's native customary rights to a section of land that is now actively planted and harvested by IOI. The local courts initially ruled that the community was indeed entitled to these customary rights but that the State could limit these rights and issue leases affecting them. The appeals court overturned the judgment in 2010 , leading to a new wave of protests by the community. Amidst this two-decades-long legal procedure over the nature and content of native customary rights, the production of palm oil has continued with little interruption.

This example connects with the RED due to IOI's membership in RSPO. Despite the ongoing dispute, IOI become a certified RSPO producer in 2004. This gave the indigenous community an alternative venue to raise concerns about the alleged land dispossession, which auditors did not find to violate RSPO's requirement for "free, prior, and informed consent" to be obtained in contested land acquisitions. Since 2013, the local community has worked with RSPO's Dispute Settlement Facility to assess whether it is in their interests to pursue resolution via the RSPO. In this case, the transparency of the RSPO's certification activities, decision-making procedures, and the presence of a dispute-resolution mechanism has provided this community with a new venue to contest their rights in a national context in which trade interests benefit from overlooking such rights and courts have opted against protecting them.

In April 2016, in an action unrelated to the Long Teran Kanan community dispute, the RPSO suspended IOI's membership after Aidenvironment complained to the RSPO that the company was expanding a different set of its plantations in Indonesia using techniques prohibited by the RSPO (RSPO 2016a). In response, IOI filed a lawsuit in Zurich claiming that the RSPO did not have the right to suspend its membership, and that IOI was "unfairly affected" (Vaughn 2016). The lawsuit was dropped just one month later (Mathiesen 2016). Shortly thereafter, in August 2016, RSPO lifted its suspension of IOI's membership upon IOI having demonstrated initial steps towards achieving compliance (RSPO 2016b). In response, Greenpeace took actions to block IOI facilities in the port of Rotterdam. IOI has continued to maintain its RSPO membership through 2017. Immediately following IOI's suspension in 2016, Unilever announced that it would no longer source palm oil with $\mathrm{IOI}$ and maintained this ban on IOI's products well after RSPO lifted its suspension. In August 2017, Unilever announced that it had seen sufficient improvements to reestablish business ties with IOI (Unilever 2017). In contrast, Nestlé also stopped sourcing palm oil from IOI upon its RSPO suspension, and has yet to change its policy towards IOI despite its renewed RSPO membership. In the meanwhile, the Long Teran Kanan dispute is still being mediated in the RSPO Dispute Settlement Facility.

This example demonstrates the potential, as well as the limitations, for transnational actions to cumulatively discipline poor corporate behavior. For example, in the formal complaints submitted to RSPO that led to IOI's suspension, resolution of the Long Teran Kanan dispute was included in the list of actions that Aidenvironment expected IOI to take in order to retain its RSPO certification (Aidenvironment 2015). This reference was included despite that the complaints which ultimately lead to IOI's suspension targeted IOI subsidiaries located in Indonesia. In this manner, the RSPO complaint and dispute resolution procedures allow for affected parties to draw together dispersed, transboundary violations of social and environmental standards into a cumulative targeted action. The transparency of audit reports, and thus corporate performance, allowed for civil society actors to assemble contestation towards the business activities of IOI's subsidiaries located across seven different states / provinces in Indonesia and Malaysia in a single critical strategy of dispute resolution. 
At the same time, this example also demonstrates how the market-driven and collaborative character of RSPO allows for businesses to quickly resume its sustainable image (within one month in this case) if they are willing to initiate a process of dispute resolution. RSPO's approach, essentially a preference for the carrot over the stick, could instead have maintained IOI's suspension until its business activities were independently audited and found to have been fully in compliance. Yet this would have frozen IOI palm oil out of the supply chains of RSPO's downstream members (Unilever, Nestlé, etc.), and also out of the EU RED framework as an automatic consequence following the suspension of RPSO certification.

This example illustrates how the RED's influence on the accountability and transparency of biofuel standards can manifest in concrete opportunities for stakeholders to contest possible rights violations arising from biofuel production. Biofuel standards with non-transparent and industry-driven governance bodies that lack public participation mechanisms in standard-setting and dispute resolution pose a challenge to these kinds of transnational actions by dispersed affected communities. The four new biofuel standards created in light of EU RED (2BSvs, Abengoa, Neste Oil \& Greenergy) all lack essential components which made these actions possible, including publicly available audit reports, public complaint procedures, and transparent dispute resolution mechanisms. In other words, the EU RED has led to a lower quality of administrative governance in biofuel standards, generally speaking, which will make it more difficult for large palm oil producers to be held publicly accountable for poor environmental and social performance. This rise in unaccountable governance resulting from RED empowers agri-industry producers through their access to the EU market as sustainable biofuel, but this comes at the expense of already marginalized communities whose opportunities to use biofuel standards as a form of contestation are curtailed by non-transparent and publicly unaccountable standard-setting organizations (see also Veitch 2007).

\section{Conclusion}

The current assemblage of the Parliament and Council's RED, the Commission in its implementing role, and non-state standards, constitutes a globally influential series of governance interactions. In its transnational delegation to voluntary schemes, the Commission avoided any systematic review of the schemes' administrative governance structures and instead emphasized functionality. By emphasizing the ability of schemes to accomplish implementation and monitoring of the RED's sustainability goals, the Commission has initiated a proliferation of new biomass standards that have less robust administrative governance structures than their precursors. The less robust structures are problematic for already marginalized communities lacking venues to raise their grievances tied to global biofuel value chains. In other words, the RED assemblage "allows energy security priorities of affluent nations to put local livelihoods in peril and benefit already privileged market actors" (Larsen et al. 2012, p. 302).

Approaching the RED through assemblage theory illustrates how transnational interactions manifest in differentiated ways for the diverse actors and interests involved in and affected by them. In this case, it illustrates how interactions can foster unaccountability at the expense of competing trade interests. By suspending judgment on the success or failure of such an interaction, it is possible to see the more intricate dynamics between competing and contradictory interests that collectively compose the assemblage. Lastly, the assemblage approach demonstrates how this interaction itself became a constituent element of the broader assemblage of institutions and procedures by which marginalized communities raise attention to their perceived injustices related to biofuel production. 
${ }^{1}$ Directive 2009/28/EC of 23 April 2009 on the promotion of the use of energy from renewable sources and amending and subsequently repealing Directives 2001/77/EC and 2003/30/EC [2009] OJ L 140/16 (hereafter "Renewable Energy Directive").

2 Ibid, arts 17-19.

${ }^{3}$ Ibid, art 18(4).

${ }^{4}$ Directive 2003/30/EC of the European Parliament and of the Council of 8 May 2003 on the promotion of the use of biofuels or other renewable fuels for transport [2003] L 123/42. See also Directive 2001/77/EC of the European Parliament and of the Council of 27 September 2001 on the promotion of electricity produced from renewable energy sources in the internal electricity market [2001] L 283.

${ }^{5}$ Renewable Energy Directive, art 3(1).

${ }^{6} \mathrm{lbid}$, preamble $\S 9$.

${ }^{7}$ Renewable Energy Directive, art 17(2-6).

${ }^{8}$ Ibid, art 17(7).

${ }^{9} \mathrm{Ibid}$, art 18(3).

${ }^{10} \mathrm{lbid}$, art 18(4).

$11 \mathrm{lbid}$, art 18(5).

${ }^{12}$ Case 25/70 Einfuhr- und Vorratsstelle für Getreide und Futtermittel v Köster et Berodt \& Co [1970] ECR 1161.

${ }^{13}$ Renewable Energy Directive, art. 23(2); see also art 21.

${ }^{14} \mathrm{Ibid}$, art. 25(2).

${ }^{15}$ Case 9/56 Meroni \& Co., Industrie Metallurgiche, S.p.A. v High Authority of the ECSC [1957-58] ECR 133.

16 Ibid, at 152.

${ }^{17}$ Council Resolution on a new approach to technical harmonisation and standards, [1985] OJ C 136/1.

${ }^{18}$ Council Resolution of 18 June 1992 on the role of European standardisation in the European economy [1992] OJ C 173/1. See art 3-6 of Regulation 1025/2012 of the European Parliament and of the Council of 25 October 2012 on European Standardisation, [2012] OJ L 316/12 (hereafter "European Standardisation Regulation").

${ }^{19}$ Case C-171/11 Fra.bo SpA v Deutsche Vereinigung des Gas- und Wasserfaches eV (DVGW) - TechnischWissenschaftlicher Verein, Judgment of 12 July 2012; Case C-613/14 James Elliott Construction Limited v Irish Asphalt Limited, Judgment of 27 October 2016.

${ }^{20}$ European Standardisation Regulation, art 2(4)(b).

${ }^{21}$ Renewable Energy Directive, art 18(4).

22 Ibid, art 18(5).

${ }^{23}$ Directive 2015/1513 of the European Parliament and of the Council of 9 September 2015 amending Directive 98/70/EC relating to the quality of petrol and diesel fuels and amending Directive 2009/28/EC on the promotion of the use of energy from renewable sources [2015] OJ L 239/1.

24 Directive 2015/1513, Article 2(6)d.

${ }^{25}$ The Commission's recognition decisions for Abengoa and Greenergy schemes expired on 30 June 2017 and have yet to be renewed. 


\section{References}

2BSvs voluntary scheme, 'Governance and Management v1.9,' released 15 September 2016, http://en.2bsvs.org/scheme-requirements-and-documents.html, last accessed 23 December 2016.

Abbott, Kenneth W, Philipp Genschel, Duncan Snidal and Bernhard Zangl (eds), International Organizations as Orchestrators (Cambridge UP 2015).

Abbott, Kenneth W and Duncan Snidal, 'Strengthening International Regulation Through Transnational New Governance: Overcoming the Orchestration Deficit' (2009) 42 Vanderbilt Journal of Transnational Law 501.

Abengoa Bioenergy, 'Annual report of the application of the RSBA standard (2013-2014)' (2014).

Aidenvironment, 'Response to the IOI Group-Aksenta verification of Aidenvironment's complain,' (2015) letter of 25 June 2015, https://www.rspo.org/files/download/f7ecb5d2ad2041e, last accessed 21 December 2017.

Bailis, Robert and Jennifer Baka, 'Constructing Sustainable Biofuels: Governance of the Emerging Biofuel Economy' (2011) 101 Annals of the Association of American Geographers 827.

Bergström, Carl Frederik, Comitology: Delegation of Powers in the European Union and the Committee System (Oxford UP 2005).

Cashore, Benjamin, Graeme Auld, Steven Bernstein and Constance McDermott, 'Can Non-State Governance "Ratchet Up" Global Environmental Standards? Lessons from the Forest Sector' (2007) 16 Review of European Community and International Environmental Law 158

Colchester, Marcus, Thomas Jalong and Wong Meng Chuo, "Sarawak: IOI-Pelita and the community of Long Teran Kanan" in Forest Peoples Programme, Conflict or Consent? The oil palm sector at a crossroads, $<$ http://www.forestpeoples.org/sites/fpp/files/publication/2012/10/sarawak-ioi-pelitaand-long-teran-kanan-september-2012-2.pdf, last accessed 23 December 2016>

Cutler, A. Claire, Private Power and Global Authority: Transnational Merchant Law in the Global Political Economy (Cambridge UP 2003).

Craig, Paul, 'The Role of the European Parliament under the Lisbon Treaty' in Stefan Griller and Jacques Ziller (eds), The Lisbon Treaty: EU Constitutitonalism without a Constitutional Treaty? (Springer 2008).

Craig, Paul and Gráinne de Búrca, EU Law: Texts, Cases, and Materials (4th edn, Oxford UP 2008).

Curtin, Deirdre 'Holding (Quasi-)Autonomous EU Administrative Actors to Public Account' (2007) 13 European Law Journal 523.

Dehousse, Renaud, 'Misfits: EU Law and the Transformation of European Governance' in Christian Joerges and Renaud Dehousse (eds), Good Governance in Europe's Market (Oxford UP 2002).

Delanda, Manuel, A New Philosophy of Society: Assemblage theory and complexity (Continuum 2006a).

------ 'Deleuzian Social Ontology and Assemblage Theory' in Martin Fuglsang and Bent Meier Sorensen (eds), Deleuze and the Social (Edinburgh UP 2006b) 250-266.

Deleuze, Gilles and Félix Guattari, A Thousand Plateaus (University of Minnesota Press 1987). 
de Sousa Santos, Boaventura Toward a New Legal Common Sense: Law, Globalization, And Emancipation (2nd edn, Butterworths LexisNexis 2002).

Eberlein, Burkard, Kenneth Abbott, Julia Black, Errol Meidinger and Stepan Wood, 'Transnational Business Governance Interactions: Conceptualization and Framework for Analysis' (2014) 8 Regulation \& Governance 1.

European Commission, 'Communication from the Commission on voluntary schemes and default values in the EU biofuels and bioliquids sustainability scheme' [2010] OJ C 160/01.

----- 'First EU sustainability schemes for biofuels get the go-ahead,' IP/11/901, 19 July 2011, http://europa.eu/rapid/press-release IP-11-901 en.htm?locale=fr, last accessed 23 December 2016.

---- 12 March 2015 letter titled “Update of Commission website, notifications and transparency measures" (2015a).

----- 'Assessment Protocol template,' released 11 November 2015 (2015b) https://ec.europa.eu/energy/sites/ener/files/documents/Assessment\%20Protocol\%20te mplate 111115.pdf, last accessed 23 December 2016.

---- 18 November 2015 letter titled "Implementation of the ILUC Directive and update of the template used for the assessment of voluntary schemes" (2015c)

----- 'Voluntary Schemes' webpage (2017) https://ec.europa.eu/energy/en/topics/renewableenergy/biofuels/voluntary-schemes, last accessed 21 December 2017.

Franco, Jennifer, Les Levidow, David Fig, Lucia Goldfarb, Mireille Hönicke and Maria Luisa Mendonça, 'Assumptions in the European Union Biofuels Policy: Frictions with Expreiences in Germany, Brazil and Mozambique' (2010) 37 The Journal of Peasant Studies 661.

German, Laura and George Schoneveld, 'A Review of Social Sustainability Considerations among EU-Approved Voluntary Schemes for Biofuels, with Implications for Rural Livelihoods' (2012) 51 Energy Policy 765.

Greenergy, 'Press Release 19 July 2011: Greenergy sustainability programme for Brazilian bioethanol becomes first voluntary scheme to gain approval under the EU Renewable Energy Directive' (2011) https://www.greenergy.com/press archives/2011/Greenergy gets RED approval.pdf, last accessed 20 December 2017.

Hennecke, Anna M, Mireille Faist, Jürgen Reinhardt, Victoria Junquera, John Neeft, and Horst Fehrenbach, 'Biofuel Greenhouse Gas Calculations under the European Renewable Energy Directive - A Comparison of the BioGrace Tool vs. the Tool of the Roundtable on Sustainable Biofuels' (2013) 102 Applied Energy 55.

International Organization for Standardization, 'ISO/IEC Guide 59: 1994, Code of Good Practice for Standardization' (1994)

----- 'International Standards and "Private Standards"' (2010)

ISCC (International Sustainability \& Carbon Certification), 'ISCC Statutes 11-03-01 v1.14' (2011).

---- 'ISCC Members' (2017) https://www.iscc-system.org/stakeholders/isccassociation/membership-list/, last accessed 20 December 2017.

----- 'Governance' (2017b) https://www.iscc-system.org/about/governance-and-transparency/, last accessed 20 December 2017.

ISEAL Alliance, 'Standard-Setting Code of Good Practice: Setting Social and Environmental Standards, version 6.0' (2014).

Larsen, Rasmus Kløcker, Norman Jiwan, Arie Rompas, Johanes Jenito, Maria Osbeck and Abetnego Tarigan, 'Towards 'hybrid accountability' in EU biofuels policy? Community 
grievances and competing water claims in the Central Kalimantan oil palm sector' (2012) 54 Geoforum 295.

Loconto, Allison and Eve Fouilleux, 'Politics of Private Regulation: ISEAL and the Shaping of Transnational Sustainability Governance' (2014) 8 Regulation \& Governance 166.

Lucas, Jake, 'Forest people 'disillusioned' in battle to protect land' Thomas Reuters Foundation News (26 November 2013).

Lytton, Timothy D. and Lesley K. McAllister, 'Oversight in Private Food Safety Auditing: Addressing Auditor Conflict of Interest' (2014) Wisconsin Law Review 289.

Mathiesen, Karl, 'Malaysian palm oil giant IOI drops lawsuit against green group' (2016) The Guardian, London, 7 June 2016.

Meidinger, Errol, 'The Administrative Law of Global Private-Public Regulation: The Case of Forestry' (2006) 17 European Journal of International Law 47.

Mitchell, Donald, "A Note on Rising Food Prices" The World Bank-Development Prospects Group, July 2008.

Mol, Arthur PJ, 'Boundless Biofuels? Between Environmental Sustainability and Vulnerability' (2007) 47 Sociologia Ruralis 297.

----- 'Environmental Authorities and Biofuel Controversies' (2010) 19 Environmental Politics 61.

NEN (Netherlands Standardization Institute), 'Netherlands technical agreement 8080: Sustainability criteria for biomass for energy purposes' (2009) 75.160.10, 75.160.20, 75.160.30.

----- 'NEN Schemabeheer v4.0' (2017) http://www.betterbiomass.com/wpcontent/uploads/2017/06/NEN-scheme-management-manual.pdf, last accessed 20 December 2017.

Overdevest, Christine and Jonathan Zeitlin, 'Assembling an Experimentalist Regime: Transnational Governance Interactions in the Forest Sector' (2014) 8 Regulation and Governance 22.

Paiement, Phillip, 'ISEAL Alliance and the Administrative Governance of Transnational Sustainability Standards' (2016) 21 Tilburg Law Review 144.

Partzsch, Lena, 'The Legitimacy of Biofuel Certification' (2009) 28 Agriculture and Human Values 413.

Pelkmans, Jacques, 'The New Approach to Technical Harmonization and Standardization' (1987) 25 Journal of Common Market Studies 249.

Perez, Oren. 'Private Environmental Governance as Ensemble Regulation: A Critical Exploration of Sustainability Indexes and the New Ensemble Politics,' (2011) 12 Theoretical Inquiries in Law 543.

Ponte, Stefano, “"Roundtabling" Sustainability: Lessons from the Biofuel Industry' (2014) 54 Geoforum 261.

Ponte, Stefano and Carsten Daugbjerg, 'Biofuel Sustainability and the Formation of Transnational Hybrid Governance' (2015) 24 Environmental Politics 96.

Ponzano, Paolo '"Executive" and "Delegated" Acts: The Sitaution after the Lisbon Treaty' in Stefan Griller and Jacques Ziller (eds), The Lisbon Treaty: EU Constitutitonalism without a Constitutional Treaty? (Springer 2008).

REDCert GmbH, 'Annual Report 2014' (2014) http://www.redcert.org/index.php?option=com content\&view=category\&id=75\&ltemi $\mathrm{d}=237$ \&lang=en, last accessed 23 December 2016.

Reinecke, J, S Manning and O von Hagen, 'The Emergence of a Standards Market: Multiplicity of Sustainability Standards in the Global Coffee Industry' (2012) 33 Organization Studies 791. 
Romppanen, Seita, 'The Role and Relevance of Private Actors in EU Biofuel Governance' (2013) 22 Review of European Community \& International Environmental Law 340.

RSPO, 'Notice to RSPO Members on the Suspension of IOI Group's Certification' (2016a) released 1 April 2016, http://www.rspo.org/news-and-events/announcements/notice-to-rspomembers-on-the-suspension-of-ioi-groups-certification, last accessed 23 December 2016.

'RSPO Statement on IOI and the Greenpeace Actions in Rotterdam' (2016b) released 28 September 2016, https://rspo.org/news-and-events/news/rspo-statement-on-ioi-andthe-greenpeace-actions-in-rotterdam, last accessed 20 December 2017.

RTRS, 'RTRS Standard for Responsible Soy Production Version 3.1' (2017).

----- 'RTRS Standard for Responsible Soy Production Version 2.0_ENG' (2013).

Sassen, Saskia, Territory, Authority, Rights: From Medieval to Global Assemblages (Princeton UP 2006).

----- 'Neither Global nor National: Novel Assemblages of Territory, Authority and Rights' (2008) 1 Ethics \& Global Politics 61.

Schepel, Harm, The Constitution of Private Governance: Product Standards in the Regulation of Integrating Markets (Hart 2005).

---- 'The New Approach to the New Approach: The Jurdification of Harmonized Standards in EU Law' (2013) 12 Maastricht Journal of European and Comparative Law 521.

Schleifer, Philip, 'Orchestrating Sustainability: The Case of European Union Biofuel Governance' (2013) 7 Regulation \& Governance 533.

Schut, Marc and Madeleine J Florin, 'The Policy and Practice of Sustainable Biofuels: Between Global Frameworks and Local Heterogeneity. The Case of Food Security in Mozambique' (2015) 72 Biomass and Bioenergy 123.

Sullivan, Gavin, 'Transnational Legal Assemblages and Global Security Law: Topologies and Temporalities of the List' (2014) 5 Transnational Legal Theory 81.

Unilever, 'Unilever responds to the RSPO decision to lift suspension of the IOI group,' (2017) https://www.unilever.com/news/Press-releases/2016/Unilever-reacts-to-palm-oilsuppliers-suspension-from-RSPO.html, last accessed 21 December 2017.

United Nations News Centre, "UN independent rights expert calls for five-year freeze on biofuel production," 26 October 2007.

Valverde, Mariana, Chronotopes of Law: Jurisdiction, Scale and Governance (Routledge 2015).

Vaughn, Adam, "Top palm oil producer sues green group over deforestation allegations" The Guardian (9 May 2016).

Veitch, Scott, Law and Irresponsiblity: On the legitimation of human suffering (Routledge Cavendish 2007).

Verburggen, Paul and Tetty Havinga (eds), Hybridization of Food Governance: Trends, Types and Results (Edward Elgar 2017).

Wood, Stepan, 'Exploring the Relationship between Administrative Norms and Competence in Transnational Governance: ISO, ISEAL and Sustainability Standards' (2016) 21 Tilburg Law Review 193.

Wood, Stepan, Kenneth W Abbott, Julia Black, Burkard Eberlein, and Errol Meidinger, 'The Interactive Dynamics of Transnational Business Governance: A Challenge for Transnational Legal Theory' (2015) 6 Transnational Legal Theory 333.

Zezza, Annalisa, 'Creating a Sustainable Market for Biofuels: Some Governance Issues' (2012) 11 EuroChoices 41. 
Zumbansen, Peer, 'Neither "Public" nor "Private", "National" nor "International": Transnational Corporate Governance from a Legal Pluralist Perspective' (2011) 38 Journal of Law and Society 50.

----- 'Defining the Space for Transnational Law: Legal Theory, Global Governance and Legal Pluralism' (2012) 21 Transnational Law and Contemporary Problems 305.

\section{Legislation and Court Judgments}

Directive 2001/77/EC of the European Parliament and of the Council of 27 September 2001 on the promotion of electricity produced from renewable energy sources in the internal electricity market [2001] L 283.

Directive 2003/30/EC of the European Parliament and of the Council of 8 May 2003 on the promotion of the use of biofuels or other renewable fuels for transport [2003] L 123/42.

Directive 2009/28/EC of 23 April 2009 on the promotion of the use of energy from renewable sources and amending and subsequently repealing Directives 2001/77/EC and 2003/30/EC [2009] OJ L 140/16

Directive 2015/1513 of the European Parliament and of the Council of 9 September 2015 amending Directive 98/70/EC relating to the quality of petrol and diesel fuels and amending Directive 2009/28/EC on the promotion of the use of energy from renewable sources [2015] OJ L 239/1.

Regulation 1025/2012 of the European Parliament and of the Council of 25 October 2012 on European Standardisation, [2012] OJ L 316/12

Council Resolution on a new approach to technical harmonisation and standards, [1985] OJ C $136 / 1$.

Council Resolution of 18 June 1992 on the role of European standardisation in the European economy [1992] OJ C 173/1.

Case 9/56 Meroni \& Co., Industrie Metallurgiche, S.p.A. v High Authority of the ECSC [1957-58] ECR 133.

Case 25/70 Einfuhr- und Vorratsstelle für Getreide und Futtermittel v Köster et Berodt \& Co [1970] ECR 1161.

Case C-171/11 Fra.bo SpA v Deutsche Vereinigung des Gas- und Wasserfaches eV (DVGW) Technisch-Wissenschaftlicher Verein, Judgment of 12 July 2012.

Case C-613/14 James Elliott Construction Limited v Irish Asphalt Limited, Judgment of 27 October 2016. 